\title{
Effect of tarragon addition on volatile compound profile and some quality paramaters of sucuk
}

\author{
Tarhun ilavesinin sucuğun uçucu bileşen profiline ve bazı kalite \\ parametrelerine etkisi
}

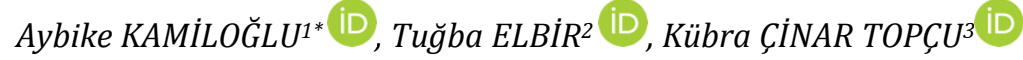 \\ 1,2Department of Food Engineering, Faculty of Engineering, Bayburt University, Bayburt, Turkey. \\ abereketoglu@bayburt.edu.tr, telbir@bayburt.edu.tr \\ ${ }^{3}$ Department of Food Processing, Aydıntepe Vocational School, Bayburt University, Bayburt, Turkey. \\ kcinar@bayburt.edu.tr
}

\begin{abstract}
The goal of the present study was to investigate the effect of tarragon and ripening period on certain quality parameters and the volatile profile of sucuk (Turkish dry fermented sausage). Tarragon was used in sucuk samples at three distinct levels $(0.25 \%, 0.50 \%$ and $0.75 \%)$, and tarragon-free samples were used as control. Analyses were performed on the 0., 3., 5., 7., 9. and 13. days of ripening time. Although the presence of tarragon did not affect $L^{*}$ and $b^{*}$ values, the $p H, a^{*}(P<0.01)$, aw $(P<0.05)$, and TBARS values of the sucuk samples were statistically affected. Tarragon demonstrated antioxidant activity in sucuk in accordance with $90 \% \pm 0.3 \mathrm{DPPH}$ scavenging activity. When the volatile profile was evaluated, the key component affected by the addition of tarragon was determined as Anisole, p-allyl-. As a result, while an antioxidative effect was detected during ripening in the presence of tarragon in sausage, undesirable changes were not observed on some quality characteristics such as $\mathrm{pH}$ and $a_{w}$.
\end{abstract}

Keywords: Tarragon, TBARS, Volatile compound, Sucuk, Fermentation

\section{Introduction}

Sucuk, is a dry fermented meat product, widely consumed in Turkey. Conventionally, it is produced using beef or buffalo meat, sheep's tail fat, salt, nitrite and various spices [1],[2] Oxidation is a change affecting the properties of foods as well as meat products [3]. Synthetic antioxidants such as butylated hydroxyanisole (BHA), butylated hydroxytoluene (BHT), tertbutylhydroquinone (TBHQ), propyl gallate (PG) are used in meat products to prevent oxidation [4]. Recently, conscious consumers have been interested in naturally sourced content. The use of natural antioxidants has gained importance in response to consumer demand. Spices and herbs are one of the most important natural sources of antioxidants [5],[6]. These sources may contain bioactive substances, phenolic mixtures and flavonoids with antioxidative effect [7].

Tarragon (Artemisia dracunculus) is a plant belonging to the Asteraceae family. It is known that different plants in this family have antimicrobial and antioxidative effects [8],[9]. Tarragon is a spice widely used in various cuisines around the world. This spice, which has a very important place in the French cuisine, has also been studied medicinally [10]-[12]. Studies on the effect of tarragon on meat and meat products are very
Öz

Bu çalıșmada tarhun ve olgunlaștırma süresinin sucuğun bazı kalite parametreleri ve uс̧ucu profili üzerindeki etkisinin araștırılması amaçlanmıştır. Sucuk örneklerinde 3 farkl seviyede (\%0.25, \%0.50 ve $\% 0.75)$ tarhun ve kontrol olarak tarhun içermeyen örnek kullanılmıstır. Analizler olgunlaşma süresinin 0., 3., 5., 7., 9. ve 13. günlerinde yapılmıștır. Tarhun varlı̆̆ı, $L^{*}, b^{*}$ değerlerini etkilemezken sucuk örneklerinin $p H, a^{*}(P<0.01), a_{w}(P<0.05)$ ve TBARS değerlerini istatistiksel olarak etkilemistir. Tarhun, göstermis olduğu \%90 \pm 0.3 DPPH süpürme aktivitesi ile uyumlu olarak sucukta antioksidan aktivite göstermiştir. Uçucu profili değerlendirildiğinde, tarhun ilavesinin etki ettiği major bileșenin Anisole, p-allyl- olduğu belirlenmistir. Sonuc olarak kullanılan konsantrasyonlardaki tarhun varlığinda, sucukta olgunlastırma sirasında antioksidatif etki tespit edilirken, $p H$ ve $a_{w}$ gibi bazı kalite özellikleri üzerinde arzu edilmeyen değişimler gözlenmemiștir.

Anahtar kelimeler: Tarhun, TBARS, Uçucu bileșen, Sucuk, Fermantasyon

insufficient in the literature [13]-[15]. Therefore, the purpose of this study is to determine the effects of A. dracunculus on sausage quality and oxidative properties during the ripening period.

\section{Material and methods}

\subsection{Determination of Antioxidative Activity of Tarragon}

1, 1-diphenyl-2-picrylhydrazyl (DPPH) method was used for this purpose. Tarragon sample $(1 / 10, \mathrm{w} / \mathrm{v})$ was diluted with ethanol and $2 \mathrm{ml}$ of $0.06 \mathrm{mM}$ DPPH solution volume was transferred to ensure mixing. The resulting mixture was kept in a dark place for $30 \mathrm{~min}$. at room temperature. After $30 \mathrm{~min}$. the absorbance analysis was carried out at $517 \mathrm{~nm}$. The values obtained were determined using the following formula as the percent free radical inhibition [14].

$\%$ free radical inhibition $=(A 0-A s) / A 0 * 100$

Where $\mathrm{A}_{0}=$ absorbance of blank and $\mathrm{A}_{\mathrm{s}}=$ absorbance of sample.

\subsection{Sucuk manufacturing}

For sucuk production, meat and fat were supplied from the producers in Bayburt and tarragon grown in Bayburt region was used. $20 \mathrm{~g}$ of $\mathrm{NaCl}, 10 \mathrm{~g}$ of garlic, $9 \mathrm{~g}$ of cumin, $7 \mathrm{~g}$ of red

${ }^{*}$ Corresponding author/Yazışılan Yazar 
pepper, $4 \mathrm{~g}$ of sucrose, $5 \mathrm{~g}$ of black pepper, $2.5 \mathrm{~g}$ of pimento and $150 \mathrm{ppm}$ of $\mathrm{NaNO}_{2}$ are contained in $1 \mathrm{~kg}$ of meat-fat mixture ( $80 \%$ of beef meat and $20 \%$ of beef meat fat). Sucuk batter was prepared with meat mincer. After mincing, powdered tarragon in various amounts $(0.25,0.50$ and $0.75 \%)$ was added to the sucuk batters and the control group was prepared without tarragon. Sucuk batters were inoculated with autochthonous Lactobacillus plantarum S91+ Stahphylococcus xylosus GM92 [16] at 7 and $6 \log \mathrm{CFU} / \mathrm{g}$, respectively. The sausage batter was portioned using casings to weigh $200 \pm 5 \mathrm{~g}$. Ripening conditions were preferred as; 1 day, $(92 \pm 2 \%$ relative humidity $(\mathrm{RH})$, $\left.24 \pm 1{ }^{\circ} \mathrm{C}\right), 2$ day $\left(90 \pm 2 \% \mathrm{RH}, 20 \pm 1{ }^{\circ} \mathrm{C}\right), 4$ day $(88 \pm 2 \% \mathrm{RH}$, $\left.18 \pm 1{ }^{\circ} \mathrm{C}\right), 2$ day $\left(88 \pm 2 \% \mathrm{RH}, 16 \pm 1{ }^{\circ} \mathrm{C}\right), 7$. day $(80 \pm 2 \% \mathrm{RH}$, $16 \pm 1 \circ \mathrm{C})$ [17].

\subsection{Physicochemical analysis}

For $\mathrm{pH}$ determination $100 \mathrm{ml}$ of distilled water was applied to the sample of 10 grams, then homogenized with Ultraturrax (IKA Werk T 25. Germany) for $1 \mathrm{~min}$. A pH-meter was used to assess the $\mathrm{pH}$ values after homogenization (Jenco Electronics. 6173) [18]. Also, moisture content of sucuk samples were determined according to Gökalp et al. [18].

\subsection{Color evaluation}

The color of the samples was determined by a colorimeter (Model CR 300. Chromometer, Minolta, Japan). The results were recorded as $\mathrm{L}^{*}$ (brightness: 100 . darkness: 0 ), a* (red: +, green: -), $b^{*}$ (yellow: +, blue: -). From every sample slice, four measurements were obtained.

\subsection{Determination of thiobarbituric acid reactive substances (TBARS) value}

$2 \mathrm{~g}$ of the samples and $12 \mathrm{ml}$ of trichloroacetic acid (TCA) solution $(7.5 \%$ TCA, $0.1 \%$ ethylenediaminetetraacetic acid (EDTA), $0.1 \%$ Propylgalate (dissolved in $3 \mathrm{ml}$ ethanol) were homogenized with Ultraturrax for $15-20$ secs. For filtering the homogenate, Whatman 1 filter paper was used. $3 \mathrm{ml}$ of filtrate and $3 \mathrm{ml}$ of thiobarbituric (TBA) solution $(0.02 \mathrm{M})$ was mixed. In a water bath, the mixture was held on at $100{ }^{\circ} \mathrm{C}$ for $40 \mathrm{~min}$., after which it was cooled under cold water. The absorbance values were read by a spectrophotometer (Spectrophotometer. Shimadzu. UV-1800) at $530 \mathrm{~nm}$ after centrifugation at $2000 \mathrm{~g}$ for $5 \mathrm{~min}$. TEP (1.1.3.3. tetra ethoxy propane) was used in the preparation of the standard and the $\mathrm{k}$ value was calculated. Results were obtained for mg malonaldehyde (MDA)/kg [19].

\subsection{6 Determination of volatile compounds}

For analyzing volatile compounds, the method presented by Kaban [16] was used. Volatile compounds of samples were determined at the last day of ripening period. The samples were shredded and moved (Supelco, Bellefonte PA, USA) to sample containers. By putting the CAR/PDMS fiber (Supelco $75 \mu \mathrm{m}$, USA) for the adsorption of free compounds, samples that were held on at a temperature of $30^{\circ} \mathrm{C}$ for $60 \mathrm{~min}$. to accumulate volatile compounds in the head space were stored for 2 hours. To classify the volatile compounds by injection into the fiber gas chromatograph (GC, Agilent Technologies 6890N), mass spectrometry (MS, Agilent Technologies 5973) was used. BD-624 was used as the column (J\&W Science, $30 \mathrm{~m}, 0.25 \mathrm{~mm}$ i.d., $1.4 \mu \mathrm{m}$ film). Initially, the oven temperature of the gas chromatograph was $5 \mathrm{~min}$. at $40{ }^{\circ} \mathrm{C}$, then progressively increased to $110{ }^{\circ} \mathrm{C}$ at $3{ }^{\circ} \mathrm{C} / \mathrm{min}, 150{ }^{\circ} \mathrm{C}$ at $4{ }^{\circ} \mathrm{C} / \mathrm{min}, 210{ }^{\circ} \mathrm{C}$ at $10^{\circ} \mathrm{C} / \mathrm{min}$. and was held for $12 \mathrm{~min}$. at the final temperature. Helium was used at a $1 \mathrm{ml} / \mathrm{min}$ flow rate as a carrier gas. Compared with the mass spectrometry library (NIST, WILEY, FLAVOR), the data obtained was evaluated. The Kovats index was calculated by regular mixes (Supelco 44585-U and 5-02251, Bellefonte PA USA).

\subsection{Statistical analysis}

Statistical analysis was conducted using the SPSS 16.0 package program. As a total randomized design with two replications, the experiment was planned. Tarragon (at the rate of $0,0.25$. 0.50 and $0.75 \%$ ) and the ripening period (0., 3., 5., 7., 9. and 13. days) were included in the model as the primary impacts. The data was evaluated by variance analysis (significance $\mathrm{p}<0.05$ and $\mathrm{p}<0.01$ ) and the multiple range test of Duncan (significance $\mathrm{p}<0.05$ ) was then performed to test the mean differences. The results were expressed as data \pm standard deviation.

\section{Results and discussion}

The $\mathrm{pH}$ values of sucuk samples $(\mathrm{p}<0.01)$ were very significantly influenced by using tarragon and the ripening duration. A lower $\mathrm{pH}$ value in the presence of tarragon relative to the control group was determined, as shown in Table 1. It can be said that, during the fermentation phase, the presence of tarragon encourages acid formation. After the third day of fermentation, the $\mathrm{pH}$ levels fell below 5 . A rise in the $\mathrm{pH}$ value was calculated during the subsequent days of ripening. It can be said that ammonia and buffering components formed in the fermentation environment and decreased electrolyte dissociation caused this rise [20].

Table 1. Effect of tarragon and ripening period on the $\mathrm{pH}$.

\begin{tabular}{|c|c|c|c|c|}
\hline & & \multicolumn{3}{|c|}{$\mathrm{T}$} \\
\hline $\mathrm{R}$ & Control & $0.25 \%$ & $0.50 \%$ & $0.75 \%$ \\
\hline 0 & $5.76 \pm 0.01^{\mathrm{a}, \mathrm{A}}$ & $5.75 \pm 0.01^{\mathrm{ab}, \mathrm{A}}$ & $5.75 \pm 0^{\mathrm{ab}, \mathrm{A}}$ & $5.73 \pm 0^{\mathrm{b}, \mathrm{A}}$ \\
\hline 3 & $4.37 \pm 0.01^{\mathrm{a}, \mathrm{E}}$ & $4.36 \pm 0.01^{\mathrm{a}, \mathrm{E}}$ & $4.33 \pm 0.01^{\mathrm{b}, \mathrm{D}}$ & $4.31 \pm 0^{\mathrm{b}, \mathrm{DE}}$ \\
\hline 7 & $4.47 \pm 0.01^{\mathrm{a}, \mathrm{D}}$ & $4.42 \pm 0.01^{\mathrm{b}, \mathrm{C}}$ & $4.40 \pm 0.01^{\mathrm{b}, \mathrm{BC}}$ & $4.32 \pm 0 \mathrm{c}, \mathrm{D}$ \\
\hline 9 & $4.59 \pm 0.01^{\mathrm{a}, \mathrm{B}}$ & $4.52 \pm 0 \mathrm{~b}, \mathrm{~B}$ & $4.44 \pm 0.02^{\mathrm{b}, \mathrm{B}}$ & $4.41 \pm 0.01^{\mathrm{c}, \mathrm{B}}$ \\
\hline 13 & $4.52 \pm 0.01^{\mathrm{a}, \mathrm{C}}$ & $4.41 \pm 0.07$ b,CD & $4.41 \pm 0.01^{\mathrm{b}, \mathrm{BC}}$ & $4.37 \pm 0.01^{\mathrm{c}, \mathrm{C}}$ \\
\hline
\end{tabular}

Significance
$\mathrm{R}$
$\mathrm{T}$
$\mathrm{R} * \mathrm{~T}$
a-c: Any two means in the same raw having the same letters in the same section are not significantly different $(\mathrm{p}<0.05)$.
A-E: Any two means in the same column having the same letters in the same section are not significantly different $\left({ }^{*} p<0.05 . * * p<0.01\right)$, NS: not significant.
SD: Standard deviation.
T: Treatment.
R: Ripening period(day).


$\mathrm{a}_{\mathrm{w}}$ values varied significantly during the ripening period $(\mathrm{p}<0.01)$ (Table 2). The addition of tarragon had a statistically significant effect on the aw values $(p<0.01)$. On the $13^{\text {th }}$ day of ripening, it was observed that the $a_{w}$ value decreased below 0.90 in all sucuk groups.

In cured fermented meat products, color is an important parameter. Table 3 presents $a^{*}$ values of sucuk samples. Although it was found that the influence of the tarragon content on the $a^{*}$ value was significant $(\mathrm{p}<0.01)$, it was found to have no effect on the $L^{*}$ and $b^{*}$ values ( $p>0.05$ ) (data not given). In the control group, although the $\mathrm{a}^{*}$ value was maximum at after 13 day ripening, it was found to be lower in the tarragoncontaining groups. The increase in quantity of tarragon contributes to a decrease in the $\mathrm{a}^{*}$ value. The lowest value in the sucuk batter and on the last day of ripening was determined when the shift in the $a^{*}$ value was discussed during ripening. Although the color in the sucuk batter was not stable, the desired cured meat color was achieved in the coming days by the development of the nitrosomyoglobin complex. It can be said that the decrease in the $a^{*}$ value at the end of ripening was due to the prevention of the oxygen interaction of sucuk samples and the denaturation of nitrosomyglobin during ripening [21],[22]. In general, discoloration of meat products coincides with lipid oxidation [23],[24]. The brown metabolites resulting from browning reactions and/or oxidation that have occurred over time may cause this decrease [25].

To determine the lipid oxidation level in meat and meat products, the TBARS value is an important parameter [26]. Table 4 presents changes in the TBARS values during the ripening phase. The tarragon content and ripening period $(p<0.01)$ significantly influenced TBARS values. TBARS values ranged from 0.6 to $0.72 \mathrm{mg} / \mathrm{kg}$ in sucuk samples after ripening $(\mathrm{P}<0.05)$. In the control group, the highest mean TBARS value was obtained. It was determined that there was a decrease in the TBARS value with the increase in tarragon content. The lowest TBARS mean values were determined in samples with tarragon (Table 4). The DPPH scavenging activity of tarragon extract was determined in this analysis to be $90 \% \pm 0.30$. There are several reports in the literature demonstrating the existence of the antioxidant effect of the tarragon plant [27]-[29]. In this study, it was found that the quantity of tarragon contributed to a reduction in the TBARS value $(p<0.05)$. Sharafati Chaleshtori et al. [15] stated that the addition of essential oil from tarragon had no significant impact on the degree of lipid oxidation of raw hamburger meatballs stored for 12 days at $+4{ }^{\circ} \mathrm{C}$. Wu and Rule [30] stated that the sensory sensitivity of lipid oxidation was above $1 \mathrm{mg} / \mathrm{kg}$ TBARS in fermented meat products. The TBARS values of the sucuk samples were estimated to be below $1 \mathrm{mg} / \mathrm{kg}$ at the end of ripening.

It was determined that, along with the increase in tarragon content, the presence of Anisole, p-allyl-, one of the allyl phenol derivatives, increased. Phenol derivative monoterpenes were reported to exhibit antioxidant activity [28]. This information explains the decrease in the TBARS mean value with the increase in anisole content in sucuk samples.

The volatile profile of fermented sucuk samples was determined to be composed of 40 compounds in total, including 3 sulphured compounds, 21 terpenes, 3 ketones, 1 ester, 1 ether, 4 aromatic hydrocarbons, 1 aliphatic hydrocarbon, 3 aldehydes, 1 alcohol, and 2 acids. Many volatile compounds may emerge during lipid oxidation. The most prominent examples of them include aldehydes, ketones, alcohols and acids [31]. The results of volatile compounds of fermented sucuk samples are presented in Table 5 . When the total volatile compound content was considered, it was determined that tarragon content had no significant effect on the volatile profile ( $p>0.01$ ). But, it was determined that tarragon content had a significant effect on Benzene, 1-methoxy-4-(1-propenyl)-, Phenol, 2-methoxy-4-(2-propenyl)-, Anisole, p-allyl-, 2,3 -Butanedione, propanoic acid and $\beta$ - myrcene compounds $(\mathrm{p}<0.05)$. Among these compounds, Phenol, 2-methoxy-4-(2propenyl)-, Anisole, p-allyl- and Benzene, 1-methoxy-4-(1propenyl)-content increased with the increase in tarragon content.

While Rabe and Krings [32] reported that lipids had a significant effect on aroma compounds, in this study, it was determined that the most important compounds affecting the sucuk aroma were terpenes and aromatic compounds. The aromatic compound content increased with the increase in tarragon content ( $p>0.01)$. The major compound in aromatic compounds was determined to be 1-allyl-4methoxybenzene(p-allyl-anisole) or estragole. Estragole, a phenylpropanoid compound, is characterized by tarragon in many studies [33]-[35].

Table 2. Effect of tarragon and ripening period on the $a_{w}$.

\begin{tabular}{ccccc}
\hline & & $\mathrm{T}$ & \\
\hline $\mathrm{R}$ & Control & $0.25 \%$ & $0.50 \%$ & $0.75 \%$ \\
0 & $0.949 \pm 0.001^{\mathrm{a}, \mathrm{A}}$ & $0.947 \pm 0.001^{\mathrm{b}, \mathrm{A}}$ & $0.949 \pm 0^{\mathrm{a}, \mathrm{A}}$ & $0.948 \pm 0.001^{\mathrm{ab}, \mathrm{A}}$ \\
3 & $0.938 \pm 0.001^{\mathrm{a}, \mathrm{B}}$ & $0.939 \pm 0.001^{\mathrm{a}, \mathrm{B}}$ & $0.939 \pm 0^{\mathrm{a}, \mathrm{B}}$ & $0.939 \pm 0.001^{\mathrm{a}, \mathrm{B}}$ \\
5 & $0.929 \pm 0.001^{\mathrm{a}, \mathrm{B}}$ & $0.938 \pm 0.001^{\mathrm{a}, \mathrm{B}}$ & $0.937 \pm 0.001^{\mathrm{a}, \mathrm{B}}$ & $0.935 \pm 0^{\mathrm{a}, \mathrm{BC}}$ \\
7 & $0.914 \pm 0.003^{\mathrm{a}, \mathrm{D}}$ & $0.930 \pm 0.001^{\mathrm{a}, \mathrm{C}}$ & $0.928 \pm 0.001^{\mathrm{a}, \mathrm{C}}$ & $0.931 \pm 0.001^{\mathrm{a}, \mathrm{C}}$ \\
9 & $0.910 \pm 0^{\mathrm{c}, \mathrm{E}}$ & $0.923 \pm 0.001^{\mathrm{a}, \mathrm{D}}$ & $0.920 \pm 0.002^{\mathrm{ab}, \mathrm{D}}$ & $0.916 \pm 0.001^{\mathrm{b}, \mathrm{D}}$ \\
13 & $0.863 \pm 0.01^{\mathrm{b}, \mathrm{F}}$ & $0.878 \pm 0.0^{\mathrm{a}, \mathrm{E}}$ & $0.864 \pm 0.001^{\mathrm{b}, \mathrm{E}}$ & $0.879 \pm 0.004^{\mathrm{a}, \mathrm{E}}$ \\
\hline Significance & & & \\
$\mathrm{R}$ & & $* *$ & \\
$\mathrm{~T}$ & & $* *$ & \\
$\mathrm{R}^{*} \mathrm{~T}$ & & $* *$ & & \\
\hline
\end{tabular}

a-c: Any two means in the same raw having the same letters in the same section are not significantly different $(\mathrm{p}<0.05)$.

A-F: Any two means in the same column having the same letters in the same section are not significantly $\operatorname{different}\left({ }^{*} p<0.05 .^{* *} p<0.01\right)$.

NS: Not significant.

SD: Standard deviation. T: Treatment. R: Ripening period (day) 
Table 3. Effect of tarragon and ripening period on a* value.

\begin{tabular}{|c|c|c|c|c|}
\hline \multicolumn{5}{|c|}{$\mathrm{T}$} \\
\hline $\mathrm{R}$ & Control & $0.25 \%$ & $0.50 \%$ & $0.75 \%$ \\
\hline 0 & $12.89 \pm 2.45^{\mathrm{a}}$ & $9.50 \pm 1.44^{\mathrm{ab}}$ & $8.30 \pm 0.28^{\mathrm{ab}, \mathrm{B}}$ & $7.36 \pm 2.28^{\mathrm{b}}$ \\
\hline 3 & $13.00 \pm 0.95^{\mathrm{a}}$ & $12.49 \pm 0.06^{a}$ & $12.71 \pm 1.94^{\mathrm{a}, \mathrm{A}}$ & $9.21 \pm 0.80^{\mathrm{b}}$ \\
\hline 5 & $13.37 \pm 1.43^{a}$ & $11.93 \pm 1.53^{\mathrm{ab}}$ & $10.02 \pm 1.45^{\mathrm{ab}, \mathrm{AB}}$ & $8.33 \pm 0.28^{b}$ \\
\hline 7 & $14.18 \pm 0.10^{\mathrm{a}}$ & $11.62 \pm 1.74^{\mathrm{ab}}$ & $10.23 \pm 0.40^{\mathrm{b}, \mathrm{AB}}$ & $8.48 \pm 1.69^{b}$ \\
\hline 9 & $13.41 \pm 1.41^{\mathrm{a}}$ & $13.15 \pm 2.58^{\mathrm{ab}}$ & $10.10 \pm 1.48 a^{b, A B}$ & $8.01 \pm 1.61^{\mathrm{c}}$ \\
\hline 13 & $13.77 \pm 0.57 \mathrm{a}$ & $9.92 \pm 2.73 \mathrm{ab}$ & $9.33 \pm 2.66 \mathrm{ab}, \mathrm{AB}$ & $6.50 \pm 2.41^{b}$ \\
\hline \multicolumn{5}{|c|}{ Significance } \\
\hline $\mathrm{R}$ & \multicolumn{4}{|c|}{ NS } \\
\hline $\mathrm{T}$ & \multicolumn{4}{|c|}{$* *$} \\
\hline $\mathrm{R}^{*} \mathrm{~T}$ & \multicolumn{4}{|c|}{ NS } \\
\hline \multirow{6}{*}{\multicolumn{5}{|c|}{$\begin{array}{l}\text { *a-c: Any two means in the } \\
\text { *A-B: Any two means in th } \\
\text { NS: Not significant. } \\
\text { SD: Standard deviation. } \\
\text { T: Treatment. } \\
\text { R: Ripening period (day). }\end{array}$}} \\
\hline & & & & \\
\hline & & & & \\
\hline & & & & \\
\hline & & & & \\
\hline & & & & \\
\hline \multicolumn{5}{|c|}{ Table 4. Effect of tarragon and ripening period on TBARS values(mg/kg). } \\
\hline $\mathrm{R}$ & Control & $0.25 \%$ & $0.50 \%$ & $0.75 \%$ \\
\hline 0 & $0.38 \pm 0^{\mathrm{C}, \mathrm{a}}$ & $0.39 \pm 0.19 \mathrm{AB}, \mathrm{a}$ & $0.38 \pm 0.2 \mathrm{~B}, \mathrm{a}$ & $0.38 \pm 0.21^{\mathrm{A}, \mathrm{a}}$ \\
\hline 3 & $0.49 \pm 0.01^{\mathrm{B}, \mathrm{a}}$ & $0.28 \pm 0.03 \mathrm{AB}, \mathrm{b}$ & $0.33 \pm 0.08$ B, bb & $0.36 \pm 0.08 \mathrm{~A}, \mathrm{bb}$ \\
\hline 5 & $0.55 \pm 0.04^{\mathrm{B}, \mathrm{a}}$ & $0.4 \pm 0.06 \mathrm{AB}, \mathrm{bc}$ & $0.29 \pm 0^{\mathrm{B}, \mathrm{c}}$ & $0.43 \pm 0.06^{\mathrm{A}, \mathrm{ab}}$ \\
\hline 7 & $0.67 \pm 0.04^{\mathrm{A}, \mathrm{a}}$ & $0.43 \pm 0.03^{\mathrm{AB}, \mathrm{b}}$ & $0.44 \pm 0.02^{\mathrm{B}, \mathrm{b}}$ & $0.40 \pm 0.01^{\mathrm{A}, \mathrm{b}}$ \\
\hline 9 & $0.50 \pm 0.02^{\mathrm{B}, \mathrm{ab}}$ & $0.60 \pm 0.08 \mathrm{~A}, \mathrm{a}$ & $0.37 \pm 0$ B, b & $0.45 \pm 0.12^{\mathrm{A}, \mathrm{ab}}$ \\
\hline 13 & $0.72 \pm 0.12^{\mathrm{A}, \mathrm{a}}$ & $0.60 \pm 0.06^{\mathrm{A}, \mathrm{b}}$ & $0.68 \pm 0.01 \mathrm{~A}, \mathrm{ab}$ & $0.63 \pm 0.04 \mathrm{~A}, \mathrm{ab}$ \\
\hline $\mathrm{M}$ & $0.55 \pm 0.12^{\mathrm{a}}$ & $0.45 \pm 0.14^{b}$ & $0.41 \pm 0.15^{b}$ & $0.44 \pm 0.12^{\mathrm{b}}$ \\
\hline \multicolumn{5}{|c|}{ Significance } \\
\hline $\mathrm{R}$ & & & & \\
\hline $\mathrm{T}$ & & & & \\
\hline $\mathrm{R} * \mathrm{~T}$ & & & & \\
\hline
\end{tabular}

*a-c: Any two means in the same row having the same letters in the same section are not significantly different $(\mathrm{p}<0.05)$.

${ }^{*} \mathrm{~A}$-C: Any two means in the same column having the same letters in the same section are not significantly different $(\mathrm{p}<0.05),(* * \mathrm{p}<0.01)$.

NS: Not significant; SD: Standard deviation.

T: Treatment.

R: Ripening period (day).

M: Mean.

Table 5. Volatile compounds of sucuk samples.

\begin{tabular}{|c|c|c|c|c|c|c|c|}
\hline & KI & Volatile Compounds & Control & $0.25 \%$ & $0.50 \%$ & $0.75 \%$ & Significance Level \\
\hline \multirow{2}{*}{ Acids } & 717 & Acetic acid & 18.10 & $12.22 \pm 0.58$ & $15.60 \pm 1.90$ & $20.96 \pm 1.10$ & NS \\
\hline & 886 & Propanoic acid & $2.35 \pm 0.06 b$ & $3.70 \pm 0.82 \mathrm{a}$ & $2.42 \pm 0.16 b$ & $1.25 \pm 0.01 b$ & $*$ \\
\hline Alcohols & 539 & Ethanol & 5.77 & $6.48 \pm 1.00$ & $3.37 \pm 1.14$ & $3.85 \pm 0.62$ & NS \\
\hline \multirow{3}{*}{ Aldehydes } & $<500$ & Propanal & 0.66 & 0.29 & 0.14 & 0.64 & NS \\
\hline & 849 & Hexanal & $0.33 \pm 0.16$ & $0.59 \pm 0.06$ & $0.71 \pm 0.37$ & $0.46 \pm 0.19$ & NS \\
\hline & 1334 & Propanal, 2-methyl-3-phenyl- & $2.82 \pm 0.27$ & $2.50 \pm 0.21$ & $3.31 \pm 0.81$ & $4.68 \pm 0.69$ & NS \\
\hline Aliphatic hydrocarbons & 500 & Hexane & $5.16 \pm 0.90$ & $3.09 \pm 3.37$ & $3.85 \pm 4.72$ & $2.71 \pm 0.32$ & NS \\
\hline \multirow{4}{*}{ Aromatic hydrocarbons } & 1133 & Benzene, 1-methyl-4-(1-methylethenly) & $1.39 \pm 0.09$ & 1.68 & $1.45 \pm 0.34$ & $1.61 \pm 0.56$ & NS \\
\hline & 1230 & Benzene, 1-methoxy-4-(1-propenyl)- & $2.96 \pm 0.56 c$ & $3.89 \pm 0.78 b c$ & $5.04 \pm 1.00 \mathrm{ab}$ & $7.07 \pm 0.94 \mathrm{a}$ & $*$ \\
\hline & 1450 & Phenol, 2-methoxy-4-(2-propenyl)- & $1.35 \pm 0.01 b$ & $1.46 \pm 0.11 \mathrm{~b}$ & $1.70 \pm 0.25 \mathrm{ab}$ & $2.38 \pm 0.40 \mathrm{a}$ & $*$ \\
\hline & 1482 & Benzene, 1,2-dimethoxy-4-(2-propenyl)- & $8.27 \pm 0.62$ & $8.32 \pm 0.82$ & $9.28 \pm 0.25$ & $79.23 \pm 1.80$ & NS \\
\hline Ester & 648 & Ethyl acetate & $0.51 \pm 0.06$ & 0.44 & 0.55 & 0.59 & NS \\
\hline \multirow[t]{2}{*}{ Ether } & 1460 & Anisole, p-allyl- & $4.25 \pm 1.01 \mathrm{~d}$ & $32.25 \pm 2.62 c$ & $38.90 \pm 7.07 \mathrm{~b}$ & $125.00 \pm 14.14 \mathrm{a}$ & $* *$ \\
\hline & 657 & 2,3-Butanedione & $4.43 \pm 0.18 \mathrm{a}$ & $3.97 \pm 0.14 \mathrm{a}$ & $3.08 \pm 0.36 b$ & $3.21 \pm 0.16 \mathrm{~b}$ & $*$ \\
\hline \multirow[t]{2}{*}{ Ketones } & 779 & 2-Butanone, 3-hydroxy- & $5.05 \pm 3.86$ & $4.43 \pm 2.09$ & $2.23 \pm 0.49$ & $6.13 \pm 1.27$ & NS \\
\hline & 1025 & 2,3-Octanedione & $0.26 \pm 0.01$ & $0.47 \pm 0.34$ & $0.27 \pm 0.07$ & $0.31 \pm 0.05$ & NS \\
\hline \multirow[t]{3}{*}{ Sulphured compounds } & $\begin{array}{l}1038 \\
<500\end{array}$ & Diallyl disulphide & $2.58 \pm 0.52$ & $3.99 \pm 1.56$ & $2.35 \pm 0.22$ & $2.46 \pm 0.45$ & NS \\
\hline & 730 & Sulfide, allyl methyl & 1.92 & $2.69 \pm 0.40$ & 2.17 & 2.62 & NS \\
\hline & 574 & Thiirane, methyl- & $21.54 \pm 0.09$ & $32.48 \pm 4.62$ & $25.09 \pm 4.26$ & $21.94 \pm 0.7$ & NS \\
\hline
\end{tabular}


Table 5. Continued.

\begin{tabular}{|c|c|c|c|c|c|c|c|}
\hline & $\mathrm{KI}$ & Volatile Compounds & Control & $0.25 \%$ & $0.50 \%$ & $0.75 \%$ & Significance Level \\
\hline \multirow{21}{*}{ Terpenes } & 944 & alpha.-Thujene & 1.25 & 0.64 & $0.55 \pm 0.03$ & 0.91 & NS \\
\hline & 950 & alpha.-Pinene & $3.58 \pm 0.34$ & $3.30 \pm 0.04$ & $3.50 \pm 0.07$ & $3.77 \pm 0.30$ & NS \\
\hline & 970 & Camphene & 1.45 & 0.44 & 0.62 & 0.45 & NS \\
\hline & 1006 & Sabinene & $0.86 \pm 0.05$ & 0.56 & 0.85 & $1.03 \pm 0.06$ & NS \\
\hline & 1005 & beta.-Myrcene & $29.87 \pm 0.34 \mathrm{a}$ & $27.46 \pm 3.60 \mathrm{ab}$ & $22.33 \pm 2.46 \mathrm{~b}$ & $11.48 \pm 0.78 c$ & $* *$ \\
\hline & 1019 & alpha.-Phellandrene & $5.31 \pm 0.01$ & $5.38 \pm 0.83$ & $4.70 \pm 0.43$ & $5.28 \pm 0.49$ & NS \\
\hline & 1026 & 3-Carene & $14.01 \pm 0.12$ & $13.28 \pm 1.03$ & $11.83 \pm 1.41$ & $12.84 \pm 0.97$ & NS \\
\hline & 1030 & alpha terpinene & $1.25 \pm 0.09$ & $1.34 \pm 0.37$ & $1.41 \pm 0.57$ & $1.27 \pm 0.32$ & NS \\
\hline & 1054 & D-Limonene & $21.28 \pm 0.27$ & $22.62 \pm 2.74$ & $21.78 \pm 2.33$ & $24.49 \pm 1.74$ & NS \\
\hline & 1065 & beta.-Phellandrene & $1.64 \pm 0.01$ & $1.72 \pm 0.38$ & $1.55 \pm 0.39$ & $1.65 \pm 0.28$ & NS \\
\hline & 1059 & O-cimene & $43.56 \pm 0.03$ & $47.69 \pm 6.14$ & $44.50 \pm 4.02$ & $44.75 \pm 1.73$ & NS \\
\hline & 1100 & $\gamma$-Terpinen & $28.99 \pm 0.86$ & $26.77 \pm 2.34$ & $23.69 \pm 3.08$ & $26.8 \pm 3.32$ & NS \\
\hline & 1240 & Terpinolene & $1.69 \pm 0.27$ & $1.40 \pm 0.36$ & $1.26 \pm 0.39$ & $1.54 \pm 0.43$ & NS \\
\hline & 1161 & linalool & $13.63 \pm 0.78$ & $14.45 \pm 1.54$ & $15.20 \pm 2.19$ & $16.68 \pm 6.17$ & NS \\
\hline & 1167 & allo-Ocimene & $0.46 \pm 0.13$ & $1.28 \pm 0.52$ & $1.54 \pm 0.25$ & $10.49 \pm 11.47$ & NS \\
\hline & 1367 & Gama elemene & $2.66 \pm 0.54$ & $2.63 \pm 0.23$ & $2.19 \pm 0.28$ & $2.89 \pm 0.79$ & NS \\
\hline & 1433 & Copaene & $3.59 \pm 0.12$ & $3.68 \pm 0.40$ & $3.61 \pm 0.23$ & $3.79 \pm 0.28$ & NS \\
\hline & 1473 & trans-caryophyllene & $1.15 \pm 0.16$ & $1.48 \pm 0.07$ & $1.39 \pm 0.16$ & $1.49 \pm 0.13$ & NS \\
\hline & 1504 & alpha.-Caryophyllene & $1.43 \pm 0.26$ & $1.21 \pm 0.28$ & $1.06 \pm 0.09$ & $1.26 \pm 0.27$ & NS \\
\hline & 1233 & Camphor & $1.36 \pm 0.33$ & $1.59 \pm 0.73$ & - & 1.85 & NS \\
\hline & & Total Volatile Compound & $294.32 \pm 43.93$ & $381.1 \pm 18.80$ & $388.26 \pm 61.80$ & $445.81 \pm 20.25$ & NS \\
\hline
\end{tabular}

a-c: Any two means in the same row having the same letters in the same section are not significantly different $\left({ }^{*} \mathrm{p}<0.05 . * * \mathrm{p}<0.01\right)$, Results are expressed in Arbitrary area units $(\mathrm{AU}) \times$ $10^{-6}$ ). NS: not significant. SD: Standard deviation. KI: Kovats index calculated for DB-624 capillary column (J \& W scientific: $30 \mathrm{~m}, 0.25 \mathrm{~mm}$ id, $1.4 \mathrm{~lm}$ film thickness) installed on a gas chromatograph equipped with a mass selective detector.

There are studies reporting that aldehyde content is an important compound in the detection of lipid oxidation in fermented meat products [35]-[39]. On the contrary, when the volatile profile of sucuk samples was evaluated, it was determined that it had no determining effect on aldehyde content. However, the propanoic acid (acid) and 2,3butanedione (ketone) content of the control group samples were found to be higher than the samples containing $0.50 \%$ and $0.75 \%$ tarragon. It can be said that this situation is caused by lipid oxidation [31].

\section{Conclusion}

In the study, it was determined that the addition of tarragon had a significant effect on the TBARS, $\mathrm{a}_{\mathrm{w}}$ and $\mathrm{pH}$ value of the fermented sucuk. Furthermore, the fact that the presence of tarragon has no effect on Hunter $\mathrm{L}^{*}$ and $\mathrm{b}^{*}$ values of the sucuk. As expected, tarragon, which is a herb with antioxidant properties, showed antioxidant activity in fermentation conditions. While tarragon had effect on the volatile profile of the product only by increasing the aromatic compounds due to the volatile compounds it contains, no significant effect on the total amount of volatile compounds was found. In conclusion, it can be said that this herb, which is included in people's consumption habits and is known to be rich in bioactive compounds, can be used for delaying lipid oxidation of the fermented sucuk at the concentrations studied. Further studies are needed to explain the mechanism of antioxidative action of tarragon in sucuk.

\section{Acknowledgement}

This work was supported by Bayburt University, Research Project Foundation.

\section{Author contribution statements}

In the scope of this study, the Aybike KAMILOĞLU, in the formation of the idea, the design, the literature review, Tuğba ELBIR, in the assessment of obtained results, the literature review and examining the results; the Kübra ÇINAR TOPÇU, the assessment of obtained results, examining results and the spelling and checking the article, contributed. All authors contributed to conducting experiments and obtaining data, writing original draft.

\section{Ethics committee approval and conflict of interest statement}

There is no need to obtain permission from the ethics committee for the article prepared. There is no conflict of interest with any person/institution in the article prepared.

\section{References}

[1] Erkmen 0, Bozkurt H. "Quality characteristics of retailed sucuk (Turkish dry-fermented sausage)". Food Technology and Biotechnology, 42(1), 63-69, 2004.

[2] Kaban G, Kaya M. "Effect of starter culture on growth of Staphylococcus aureus in sucuk". Food Control, 17(10), 797-801, 2006.

[3] Gray J, Gomaa E, Buckley D. "Oxidative quality and shelf life of meats". Meat Science, 43, 111-123, 1996.

[4] Karre L, Lopez K, Getty KJ. "Natural antioxidants in meat and poultry products". Meat Science, 94(2), 220-227.2013.

[5] Chipault J, Mizuno G, Hawkins J, Lundberg W. "The antioxidant properties of natural spices a, b". Journal of Food Science, 17(1-6), 46-55, 1952.

[6] Embuscado ME. "Spices and herbs, Natural sources of antioxidants-a mini review". Journal of Functional Foods, 18, 811-819, 2015.

[7] Rubió L, Motilva M-J, Romero M-P. "Recent advances in biologically active compounds in herbs and spices, a review of the most effective antioxidant and antiinflammatory active principles". Critical Reviews in Food Science and Nutrition, 53(9), 943-953, 2013.

[8] Deans S, Svoboda KP. "Antibacterial activity of French tarragon (Artemisia dracunculus Linn.) essential oil and its constituents during ontogeny". Journal of Horticultural Science, 63(3), 503-508, 1988.

[9] Mumivand H, Babalar M, Tabrizi L, Craker LE, Shokrpour M, Hadian J. "Antioxidant properties and principal phenolic phytochemicals of Iranian tarragon (Artemisia dracunculus L.) accessions". Horticulture, Environment, and Biotechnology, 58(4), 414-422, 2017. 
[10] Swanston-Flatt SK, Day C, Bailey CJ, Flatt PR. "Evaluation of traditional plant treatments for diabetes, studies in streptozotocin diabetic mice". Acta diabetologia latina, 26(1), 51-55, 1989.

[11] Sayyah M, Nadjafnia L, Kamalinejad M. "Anticonvulsant activity and chemical composition of Artemisia dracunculus $L$. essential oil". Journal of Ethnopharmacology, 94(2-3), 283-287, 2004.

[12] Eisenman SW, Poulev A, Struwe L, Raskin I, Ribnicky DM. "Qualitative variation of anti-diabetic compounds in different tarragon (Artemisia dracunculus L.) cytotypes". Fitoterapia, 82(7), 1062-1074, 2011.

[13] Tanabe H, Yoshida M, Tomita N. "Comparison of the antioxidant activities of 22 commonly used culinary herbs and spices on the lipid oxidation of pork meat". Animal Science Journal, 73(5), 389-393, 2002.

[14] Kulisic T, Radonic A, Katalinic V, Milos M. "Use of different methods for testing antioxidative activity of oregano essential oil". Food chemistry, 85(4), 633-640, 2004.

[15] Sharafati Chaleshtori R, Rokni N, Rafieian-Kopaei M, Deris F, Sharafati Chaleshtori A, Salehi E. "Use of tarragon (Artemisia dracunculus) essential oil as a natural preservative in beef burger". Italian Journal of Food Science, 26(4), 427-432, 2014.

[16] Kaban G. Geleneksel Olarak Üretilen Sucuklardan Laktik Asit Bakterileri İle Katalaz Pozitif Kokların İzolasyonuİdentifikasyonu, Üretimde Kullanılabilme İmkânları ve Uçucu Bileşikler Üzerine Etkileri. Atatürk Üniversitesi, Doktora Tezi, Erzurum, Türkiye, 2007.

[17] Kamiloğlu A, Kaban G, Kaya M. "Effects of autochthonous Lactobacillus plantarum strains on Listeria monocytogenes in sucuk during ripening". Journal of Food Safety, 2019. https://doi.org/10.1111/jfs.12618

[18] Gökalp H, Kaya M, Tülek Y, Zorba O. Guide for Quality Control and Laboratory Application of Meat Products. Erzurum, Turkey, Atatürk University, 2001.

[19] Lemon D. An Improved TBA Test for Rancidity. Halifax, NS, Canada, Halifax-Laboratory New Series Circular, 1975.

[20] Demeyer D, Vandekerckhove P, Moermans R. "Compounds determining $\mathrm{pH}$ in dry sausage". Meat Science, 3(3), 161-167, 1979.

[21] Kayaardı S, Gök V. "Effect of replacing beef fat with olive oil on quality characteristics of Turkish soudjouk (sucuk)". Meat Science, 66(1), 249-257, 2004.

[22] Bozkurt H, Bayram M. "Colour and textural attributes of sucuk during ripening". Meat Science, 73(2), 344-350, 2006.

[23] Sebranek J, Sewalt V, Robbins K, Houser T. "Comparison of a natural rosemary extract and BHA/BHT for relative antioxidant effectiveness in pork sausage". Meat Science, 69(2), 289-296, 2005.

[24] González-Ríos H, Dávila-Ramírez J, Peña-Ramos E, Valenzuela-Melendres M, Zamorano-García L, IslavaLagarda T, et al. "Dietary supplementation of ferulic acid to steers under commercial feedlot feeding conditions improves meat quality and shelf life". Animal Feed Science and Technology, 222, 111-121, 2016.

[25] Gök V, Obuz E, Şahın M, Serteser A. "The effects of some natural antioxidants on the color, chemical and microbiological properties of sucuk (Turkish dryfermented sausage) during ripening and storage periods". Journal of Food Processing and Preservation, 35(5), 677-690, 2011.
[26] Shahidi F, Yun J, Rubin L, Wood D. "The hexanal content as an indicator of oxidative stability and flavour acceptability in cooked ground pork". Canadian Institute of Food Science and Technology Journal, 20(2), 104-106, 1987.

[27] Kordali S, Kotan R, Mavi A, Cakir A, Ala A, Yildirim A. "Determination of the chemical composition and antioxidant activity of the essential oil of Artemisia dracunculus and of the antifungal and antibacterial activities of Turkish Artemisia absinthium, A. dracunculus, Artemisia santonicum, and Artemisia spicigera essential oils". Journal of Agricultural and Food Chemistry, 53(24), 9452-9458, 2005.

[28] Chaleshtori RS, Rokni N, Razavilar V, Kopaei MR. "The evaluation of the antibacterial and antioxidant activity of Tarragon (Artemisia dracunculus L.) essential oil and its chemical composition". Jundishapur Journal of Microbiology, 2013. https://doi.org/10.5812/jjm.7877

[29] Durić K, Kovač-Bešović E, Nikšić H, Sofić E. "Antioxidant Activity of water extracts and essential oil of Artemisa dracunculus L., Asteraceae". Medical Journal, 19(2), 94-99, 2013.

[30] Wu W, Rule D, Busboom J, Field R, Ray B. "Starter culture and time/temperature of storage influences on quality of fermented mutton sausage". Journal of Food Science., 56(4), 916-919, 1991.

[31] Viallon C, Berdagué J, Montel M-C, Talon R, Martin J, Kondjoyan N, et al. "The effect of stage of ripening and packaging on volatile content and flavour of dry sausage". Food Research International, 29(7), 667-674, 1996.

[32] Rabe S, Krings U, Berger RG. "Initial dynamic flavour release from sodium chloride solutions". European Food Research and Technology, 218(1), 32-39, 2003.

[33] Zeller A, Rychlik M. "Impact of estragole and other odorants on the flavour of anise and tarragon". Flavour and fragrance journal, 22(2), 105-113, 2007.

[34] Arabhosseini A, Huisman W, Van Boxtel A, Müller J. "Longterm effects of drying conditions on the essential oil and color of tarragon leaves during storage". Journal of Food Engineering, 79(2), 561-566, 2007.

[35] Gholivand MB, Yamini Y, Dayeni M. "Optimization and comparison of ultrasound-assisted extraction of estragole from Tarragon leaves with hydro-distillation method". Analytical and Bioanalytical Chemistry Research, 1(2), 99-107, 2014.

[36] Ordóñez JA, Hierro EM, Bruna JM, Hoz Ldl. "Changes in the components of dry-fermented sausages during ripening". Critical Reviews in Food Science and Nutrition, 39(4), 329-367, 1999.

[37] Olivares A, Dryahina K, Navarro JL, Smith D, Spanel P, Flores M. "SPME-GC-MS versus selected ion flow tube mass spectrometry (SIFT-MS) analyses for the study of volatile compound generation and oxidation status during dry fermented sausage processing". Journal of Agricultural and Food Chemistry, 59(5), 1931-1938, 2011.

[38] Olivares A, Navarro JL, Flores M. "Distribution of volatile compounds in lean and subcutaneous fat tissues during processing of dry fermented sausages". Food Research International, 42(9), 1303-1308, 2009.

[39] Lorenzo JM, Bedia M, Bañón S. "Relationship between flavour deterioration and the volatile compound profile of semi-ripened sausage". Meat Science, 93(3), 614-620, 2013. 